Anny Wynchank

Prof Anny Wynchank is a research associatein the School of Languages and Literatures of the University of Cape Town, South Africa. E-mail: anny.wynchank@uct.ac.za

\title{
In the wings of the ethnography stage: Michel Leiris' scientific pursuit and existential quest
}

In the wings of the ethnography stage: Michel

Leiris' scientific pursuit and existential quest

This paper analyses the attitude of a French surrealist writer and ethnographer, Michel Leiris, who accompanied the expedition led by Marcel Griaule, from Dakar to Djibouti (1931-33), as the archivist-secretary of this official "mission". In fact, Leiris participated actively in the ethnographic activities of the team. He kept a detailed account and recorded the methods used to acquire the objects collected. These methods were not always honest, but Leiris attempts to exonerate the team by pointing out that they were acting for the advancement of science and knowledge. Later, he ascribed ethnography an important role: to revalorise cultures which had been unjustly underrated. Leiris expected that his participation in the expedition would also allow him to encounter a different reality and meet the Other, hence to reduce his introspective tendencies and existential malaise. Realising these expectations were unfulfilled, he chose for his book the title Phantom Africa, which denied "full existence" to that continent. However, his account is of great interest to us because it reveals the mentality and attitude of an early $20^{\text {th }}$ century surrealist ethnographer. Key words. Afrique fantôme, Michel Leiris, travel writing,

\section{Introduction}

At the beginning of the 20th century, ethnography was not a well established discipline. It was not even well defined, without any recognised texts, methodology, university chairs, etc. But it was a science of human "races" which, in James Clifford's words, abandoned "the distinction between high and low culture" and offered "a levelling and a reclassification of familiar categories" (Clifford 1988: 129). Exploring the unknown, it "denoted aradical questioning of norms, and an appeal to theexotic, theparadoxical, theinsolite" (Clifford 1988: 129). For these reasons, it appeal ed greatly to the French surrealists of the 1920s and 1930s, who were searching beyond the known, given and familiar reality, for another reality, a "sur-reality" mysterious, rich, unwonted and what thesurreal istAndréBreton deems to bela vraievie (thetrue life) (Breton 1952).

It is therefore easy to understand why the French surrealist writer Michel Leiris was keen to participatein the expedition from Dakar to Djibouti, led by hisfriend, the ethnographer Marcel Griaule. Leiris wasto bethe "secretary-archivist" of theteam. In fact, he also participated actively in the ethnographic activities of the group, then 
starting histraining as an ethnographer, eventually becoming a full timeethnographer. The expedition lasted al most two years, from May 1931 to February 1933, during which time, Leiriskept a very detailed journal, totalling 533 pages. Leiris' diary is of great interest to usnotonly becauseit recounts theactivities of a team of ethnographers in Africa in the 1930s, describing how they collected information and artefacts, but al so becauseit gives us an insight into themind of a particular surreal ist-ethnographer, his feelings, thoughts and attitudetowards the African people, his dreams and his fears.

This paper will investigatetheteam'sactivities, as recounted by Leirisand examine theFrench surrealist's expectations and attitude during the "mission".

\section{The mission}

Marcel Griaule's "mission", underwritten by theFrench legislaturewasthevery first ethnographicexpedition undertaken officially on behalf of thegovernment. It opened the era of great French ethnographic field work. Until then, those researchers who had founded and enriched thescience- E. Durkheim, M. Mauss, L. Lévy-Bruhl - had done so virtually without leaving their desks. The term "mission" is significant. It places the expedition in the realm of officialdom and within the framework of colonialism, immediately suggesting the "confident gestures of a stable subject who conquers, instructs, converts, describes, admires, represents [... ] other peopleand their worlds" (Clifford 1988: 168). It functions as an "all-purpose term for any redemptive colonial errand, whether military, evangelical, educational, medical or ethnographic" (Clifford 1988: 168).

Yet, the surrealists - Breton, Bataille, Desnos, Artaud, Leiris - had always stood firmly against colonialism. Leirishad even once been arrested by the police, as hewas haranguing a crowd from an open window at a banquet given in honour of thepoet Saint Pol Roux - he was denouncing France's colonial policy in Morocco. The surrealists deemed Africa to havebeen handed over and lost to zealous missionaries, bovine army officers, inept administrators and incapable colonial officials. At the time of the great Exposition Coloniale (1931) in Paris, organised by the French authorities to exalt the concept of "LaGrande France" and to promotenationalism, the surrealist slogan "Do not visit the Colonial Exhibition" reminded people that Africa was a place of exploitation, oppression, forced labour and daily killing. Although in 1931, Leirishad al ready distanced himself from the surrealists' group, hestill shared their views on colonialism. So why does hejoin Griaule's "mission" and support this official colonial venture? What kind of benefit did he expect to obtain from this expedition? 


\section{Reasons for Leiris'involvement}

First, ethnography offered him thechance to encounter another reality and another humanity - to meet the Other. Also, hehad personal reasons, which herevealsin the Preamble to the third edition of this diary published in 1981 (A friquefantôme, 3). ${ }^{1} \mathrm{He}$ had hoped that scientific observation in a remoteland, and real contact with other peoples would transform him and cure his depression. Trying to understand the Other would possibly bring oblivion of theSelf. Also, he washoping that themany activities of the ethnographer - collecting, labelling, classifying, informing, etc. would help him to overcome hisobsessions.

This journal, intended to bethelogbook of theexpedition, metamorphosed into a privatediary. Leirisjustifies his subjectivity. Hestates in a project for a preface which appears in the middle of the book: "Writing subjectively, I increase the value of my testimony by showing that at every moment, I amfully aware of my worth as a witness" (213). ${ }^{2}$ "O penly exhibiting the personal coefficient allows the calculation of error. By pushing subjectivity to the extreme, one reaches objectivity" and gains "maximum truth" (213). ${ }^{3}$ Thus, his perception of the Other and his attitudetowards the people and his work are often coloured by hisstateof mind which heopenly communicates to his readers.

\section{The team's tactics}

Not only does Leiris writeabout the customs, dances, crafts, religious ceremonies of the populations amongst whom the expedition is collecting and not only does he describetheir utensils, musical instruments, objects of worship, etc., but healso frankly recounts the activities of the team and the methods they usefor collecting objects, so introducing us to thewings of theethnography stage.

Most often, objects collected by the group are bought from villagers. But some ritual articles cannot be purchased, so two possibilities arise. Sometimes, an implicit understanding is reached, an arrangement which will allow the former owners to saveface. Thus, in Mali, someritual masks which cannot be sold, are "requisitioned" by theFrench mission. The dancers who givethemasksto the ethnographers haveno choice in the face of an official order. Quite independently, these dancers receive presents - not to pay for the masks, but nominally astokens of friendship (121) - and the two operations are officially divorced from each other. But if the ethnographers cannot obtain the objects they desire from the villagers by any other means, Leiris reveals that they resort to theft. Thus, theinhabitants of Yougo Dogolon refuse "with awe" to sell somerain statuettes which Griaulewants to buy, becauseto removethese objectsfrom the village would betantamount "to taking away the life of the country" (125). ${ }^{4}$ So Griauleis told by a youth, who isalmost in tears at theidea of the calamities this impious gesture would unleash. Leiris then recounts how he conceals one of 
thesestatuettes in his shirt. Later, it is hidden insidea large closed green umbrellaand thussurreptitiously removed.

When they encounter difficulties during the day, they act at night. Thus, in Sanga, they havenoticed a beautiful wooden statue. So, "Schaeffner and I decidethat tonight, we will go to fetch it" writes Leiris that day (128). ${ }^{5}$

They set precedents for their African hel pers who emulate them. So two young Africans working for them spirit away the fibre costumes from the cave of the masks. In Bla (Mali), Griaule becomes irritated by thelengthy and complicated negotiations necessary to acquire theKono, the most sacred fetish and pivot of religious life for the villagers. So, whilewaiting, hefirst hel ps himself to two flutes which hehides in his bootsand then rearranges the objects in thecaveto conceal theflutes' disappearance (82). Then, since the villagers do not want to part with theKono, hethreatens them with thepolicewho, heclaims, arehidden in histruck, if the fetish is not handed to him in exchangefor 10 francs. "Ghastly blackmail" ( 82), ${ }^{6}$ writes Leiris, who describes theterror and the panic caused in the village by thisspoliation. All the villagers flee in horror as the ethnographers leavethe deserted villagein deadly silence, taking the Kono with them. "Thevapours of this sacrilegeriseto our heads, and in onejump, we find ourselves propelled onto a plane much above ourselves" (82). . Before leaving Dyabougou, they steal another Kono by surreptitiously entering the consecrated hut in which it is kept. "My heart beats hard insidemy chest, as, sinceyesterday's scandal, I perceivetheenormity of the deed wecommit" reveals Leiris (83). ${ }^{8}$

Further east, in Abyssinia, their deeds are equal ly objectionable. In regions which have been Christianised, they replace church paintings with copies quickly executed by a member of theteam and then taketheoriginal s with them. When they discover they cannot smugglethenation's ritual objects and church articles out of thecountry and becausethey fear being caught red handed by thecustoms with an altar piece they wanted to take out, they destroy the evidence by burning thealtar piece, after having copied the motif which decorated it. The discovery of the original by the customs officials "would certainly haveprovoked a massacre" (469), ${ }^{9}$ states Leiris. The inventory they are requested to present to thecustoms is totally false. In the secret compartments of false bottomed cases and trunks, they hide books of magic, old parchments, secret documents such as records of the census numbering slaves and possessed inhabitants, which the Abyssinian authorities do not wish to be disseminated. They roll up paintings in skins, and wrap them to makethem look like other packages. In order to hidea very old painted triptych, they cover it with sheets of paper, on which the very same motifs have been drawn and roughly painted by Roux, one of theteam. It will passas a merecopy of the genuineartide(473), which in fact, it is covering. 


\section{Leiris' attitude}

Westated earlier that one of the reasons why Leiris had joined Griaule's expedition was to try and alleviatehis existential malaise, whilegiving himself wholeheartedly to ethnological activities. So, he questions informants and labels and classifies specimens. Relief and excitement result from theintoxicating effects of this scientific research. Like a detective on a trail, he notes his pleasure when discovering in an abandoned village, a ropewhich had been used to tiethesacrificial sheep offered to sacred crocodiles. Hefeels thethrill of a sleuth led from oneclueto another, from one enigma to another, uncovering the trail of truth (52). The success of the team in purchasing a large mask enlivens his day (60). His boredom and malaise disappear with thepowerful excitement caused by thetheft of cult objects. Whilestealing one particular Kono, henotes that hefeels himself living fully and his heart beats hard. When there are no moreKonos to bestolen in one area, he is regretful, but not, he reveals, for the same reason as Griaule. "What excites me", hewrites, "is theidea of profanation" (84). ${ }^{10} \mathrm{H}$ efeels that heisthen lifted onto the place of the Gods, or is on a par with demons.

Sometimes, however, Leiris' moral conscience is awakened. When he becomes aware of the degree of inviolability of the white man, he is filled with shame and disgust. Thus, oneday, when heentersa hut with a knife to cut away a Kono from the ropes that bind it to the wall, hebecomes awarethat two men - in fact not threatening at all, he adds - are following him. "I realise with amazement which after a while turns to disgust, that you feel jolly sure of yourself when you area whiteman and you're holding a knife in you hand" (83). ${ }^{11}$ But he does not question the act itself which he justifies morally, expressing the feelings of his colleagues which are for the advancement of science and knowledge, so exonerating the actions of the research workers. They believe firmly they are acting for a good cause (3). Leiris clears the ethnographers of any blame. Is spoliation with a scientific objective still spoliation? Thesestolen objects, left to their legitimate proprietors would deteriorate, whereas at the Trocadéro or at the Musée del'Homme, in Paris, they will be preserved for ever.

One of the tasks of the "mission" was to enrich the French N ational Collection, and enrich it, they did! They brought back a booty of "3500 ethnographic objects, [... ] six thousand photographs, a large collection of Abyssinian paintings, threehundred manuscripts and amulets, notations of thirty languagesand dialects and hundreds of recordings, 'ethnographic observations', botanical specimens, and so on" (Clifford 1988: 137).

Unlikethewriter AndréMalraux, Leirisnever questioned the value of exhibiting theseobjects out of context, torn away from the social and cultural milieu which had conceived them and later labelled as "African art" by European intellectuals, writers such as GuillaumeApollinaire or AndréBreton, and painters such as Picasso. Still, somewereconscious of this desecration. In 1955, two famousfilm-makers, ChrisMarker 
and Alain Resnais, showed African statues in their film, Les statues meurent aussi (Statues also die), which had been taken away from their milieu and displayed in European museumsas objets d'art. Thefilm depicts how thestatues lost their meaning and were "mummified" assoon asthey wereseparated from their nativeenvironment. This film, which denounced the brutality of colonialism, was confiscated by the French Government and held for ten years before being released (Diawara 1992: 23). Thewriter AndréMal raux, later French Minister of Culture, when visiting the Musée du Trocadéro, was sickened by the sight of dust covered masses of African masks, statuettes, cult objects, etc. in that dark, dank place. "A flea market", he exclaimed. "You could only see the Abyssinian icons if you crouched and used the light of a cigarettelighter," herecalls with horror (Malraux 1976: 303). ${ }^{12}$ But at that stage, Leiris was not concerned with the ultimate display of the collected objects.

Sometimes, villagers complain to theauthorities. Oncea telegram from the French Governor requests Griaule to hand back a mask "requisitioned" in San, which its owners redaim (84). So the mask is given back immediately. Leiris simply exonerates the activities of the team by showing that theFrench authorities behave in a worse way: "It is easy to answer those officials who criticise our audacity in our dealings with theBlacks, for as long as Africa is submitted to a regime as iniquitous as that of taxation, compulsory dues and military service, they cannot be too particular about objectstaken away, or bought too cheaply" (89). ${ }^{13}$

However some of the actions of theteam, considered as misdemeanours by the local authorities, do havea humanitarian objective. Thus, in Abyssinia, they contravene thelaws of the country and buy slaves with theintention of freeing them, on leaving the country. This causes them a great deal of trouble on their departure.

The disclosures Leirismadein hisJournal provoked Marcel Griaule's anger and strained the relationship between thetwo men after its publication. As Leiris later admitted in hisF iveEthnographical Studies (Leiris 1950), theethnographer undermines his own survival if he speaks too frankly and divulges the secrets of his art and actions. Hemustchosebetween ethnography and truth and sometimes, truth must be sacrificed to avoid diplomatic incidents, because ethnographic missionsare usually financed by governments and are answerableto the official powers which sponsor them.

\section{Leiris and the inhabitants}

Leiris' diary is of interest because it reveals theattitude of a surrealist-ethnographer towards theinhabitants of the region hetraverses. In spite of his desireto encounter and know theOther, whilein WestAfrica, Leiris does nothaveclosecontact with the inhabitants of the regions through which he is travelling. He finds them uncouth and stupid and often loses patience with hisinformants. Their inability to understand, 
and what he calls their blunders, irritate him. Their contradictions drive him to hysterics. Furious one day, because one of theservants has goneswimming instead of folding his master's bed, he violently kicks his dish of grilled shoumbra (chick peas) which go flying (269). Heeven strikes a villager because hefinds that theman does not work energetically enough, in spite of his physical strength. When one of the informants leaves him in the lurch, he writes: "These Blacks, they areall the same! There isonly oneway to makethem function!The cane!" (172). ${ }^{14}$ But heretracts these words when heremembers the shocking treatment which victimises the Africans: lack of job security, harassment, forced labour and prison, "often for crimes which are crimes only in our eyes" (173), ${ }^{15}$ writes Leiris. And heexclaims: “Thesemen, perhaps not particularly likable, but neither worse not more stupid than anyone else; how shameful it isto treat them in this way under the guise of civilisation!" (173). ${ }^{16}$

Astheteam advances eastwards, Leiris' contacts with thenatives change. Heloses his indifference and coldness. In Abyssinia, he wants to penetrate and understand the mentality of the populations amongst which the team is collecting data; so he participates in their rites. In the Gondar region, wheretheteam spends several months, heengulfshimself in thevillagers' beliefs-doubtlessly, once again a way of forgetting his malaiseand mitigating the effects of his depression. Heloses himself in the world of thezars, those spirits who keep close to human beings, protecting, punishing them and intervening constantly in their affairs. $\mathrm{Now}$, he is no longer motivated by the merescientific curiosity of theinvestigator. He participates intensely in the rites and thesacrifices of thezars and immerses himself in the supernatural atmospherewhich prevails in Gondar. One day, after he has "received" blood - hedrank the blood of a sacrificed cockerel and was anointed with it - hefeels "very separate, very holy and chosen" (443). ${ }^{17}$ The next morning, astonished by his voracity the previous night, when he realises that he almost entirely devoured the two large chickens he has offered as a sacrificeto thezars, heknowsthat hewas the "horse", or receptacle, of the zar - hewas filled and possessed by thezar. "Itmust have been thezar who ate, not the 'horse'; I could never credit myself with such a capacity for food", hewrites (443). ${ }^{18}$ He is indignant when he thinks another sacrifice he offered for a woman was not conducted strictly according to therites. He fears her zar would not descend on her while sheis drinking the sacrificial blood. But heis reassured when the son of this woman provides proofs that the sacrifice was indeed conducted according to the rules.

Only once does Leiris question the authenticity of these rites. Could all this bea spectacle produced for the benefit of the Frendjis (the French)? he wonders. "Poor awolyas, what desperateefforts, and what toil and sweat to reach their trancestate, in their histrionic frenzy!" (401). ${ }^{19}$ But Leiris never doubts the zars' reality. For this surrealist, the invisible world of the spirits, of thezars, is just as real as the visible world which surrounds him. The problem - and the danger - for this man avid for 
novelty, mystery and escapism, is that everything eventually becomes too familiar, and thus, banal. "The zars have become my family members" he regretfully writes (401). ${ }^{20}$ This feeling brings boredom again. The fantastic becomes worn, trite and commonplace, and herelapsesinto his depression.

\section{The myth of Africa}

Leiris' attitude differs greatly from that of many other European intellectuals who visited Africa at about the same time. They adhered to theevolutionist theory, then prevalent. TheFrench writer AndréGide, for instance, travelling in Congo and Chad, fiveyears before Leiris, in 1926, had wanted to observe "mankind at the dawn of time" and "without civilisation" (Gide 1930: 21). ${ }^{21}$ He had only conceded the Africans "a numb, stagnant mind, steeped in thick night, most of the time" (Gide 1954: 765). ${ }^{22}$ Observing "the savage, the primitive" had allowed him, a "civilised man", to know himself better, because "deeply buried under the sediments patiently laid by culture", in "each of us", he writes, "lies the 'barbarian self' which it isfascinating to discover in its original form" (Gide 1988: 35). ${ }^{23}$ Thus, Gidedid not grant the African "natives" amongst whom hewas travelling, any spirituality, culture or religious beliefs. Going to Congo and to Chad, he waslured by themyth of a virgin Africa, a land and man beforeculture, wherehewould encounter lebon sauvage, thenoblesavage, unspoilt and closeto nature.

It was the same search for a myth, that of a virgin Africa, which often prompted other travellers to visit thoseregions. Thus, theSouth African painter IrmaStern also travelling in Congo, was seeking, in thewords of Patricia Davidson, "a place of romance and mystery", "a paradiselost" (Davidson 1993: 34, 36), which shetried to capturein her paintings.

Leiris is also seeking a myth in Africa, which he finds in Abyssinia. Thestifling heat, the devouring sun, the maddening wind of Gondar (225) belong to themyth of Africaand fulfil his expectations. Near Fachoda, headmires thenatives, theShillouks, "those splendid savages, so nonchalant, so unexpected and at the same time so astonishingly similar to those that one expects" (223). ${ }^{24} \mathrm{H}$ ere, reality coincides with themyth. "At last, here is AFRICA" hewritesin Gedaref, "theland of 50 degrees in the shade, convoys of slaves, cannibal feasts, skulls emptied of all that has been eaten, corroded and lost" (225). ${ }^{25}$ In Gondar, the family of Malkam Ayyahou, whom hevisits frequently, comesfrom another age. It is "a Biblical monument" $(434)^{26}$ and belongs to the myth. But unlike André Gide and the evolutionists, Leiris grants a strong spirituality to thepeopleamong whom heis collecting data. What is more, herespects their beliefs and even, immerses himself in them.

Other Europeans, understandably themissionaries, had no regard for the Africans' religious creed. For instance, William Burton lived in Central Africa for morethan 40 
years and gathered an important collection of Luba masks and artefacts for the Department of Bantu Studiesat theUniversity of the Witwatersrand in Johannesburg. Healso left important ethnographic notes, photographs, water colours, paintings, etc. Although heacknowledges thespirituality of the people of Congo, and although he did agree they possessed an intricate set of traditions and customs within their religious creed, hisonly aim was to eradicatethesebeliefs, convert the "natives" and savetheir heathen souls. "Hisgazepersistently pierced thesurfacein order to penetrate beliefs thathehoped to alter" (Davidson 1993: 34). On thecontrary, it seems that Leiris dreamt of some synchretic religion in which Christianity and Animism would be combined, of a fusion with the cosmos, a state which his "civilised" compatriots could no longer achieve.

\section{Conclusion}

Although, from the ethnographer's point of view, theexpedition was a success and brought back treasured information and precious objects, for Leiris himself, this adventurein Africa ended in a doublefailure. On a personal level, hisinitial misgivings were well founded. His isolation and solitude had proved deleterious and had encouraged introspection. Ashehad suspected from thestart, "travels do not change one. [...] Sadly, you stay what you al ways were" (181). ${ }^{27} \mathrm{He}$ had not been mistaken. From the beginning, hehad feared that this involvement in ethnography might not beableto tear himfrom his dreamer's subjectivity. Hehad remained thesameanguished man - hence his discomfiture. It was this personal disappointment which had prompted the title he had chosen for his narrative on his return, A frique fantôme Phantom Africa, a title which denied "full existence" $(3)^{28}$ to that continent where, although he had found much, total deliverance had eluded him. Such was the explanation hegavefor histitlein the preambleto thethird edition of thebook (3). He had suffered afurther disillusionment because themythical Africahethought hehad discovered had masked the authentic Africa and its burning human problems. He had been incapable of seeing real ity. That was the second and moreseriousfailure, acknowledged in thePreface to his second edition of 1951. Leirishad hoped that the activities proper to the ethnographer would foster better communication with the peopleamongst whom he wastravelling. But hediscovers they remain "shadows" (532), for "H uman Sciences remain a scienceand detached observation cannot, on its own, establish contact. Perhaps by definition, it implies exactly theopposite, because the mental attitude suited to theobserver should bean impartial objectivity alien to any effusion of sentiment" (8). ${ }^{29}$

Only in Abyssinia did Leiris feel closer to the population. This was not, he explained, because its ancient Christianity drew it, culturally, closer to Europe, but becauseit wasnotacolony. There, hefelt morein contact with the people, than in any 
other country through which theteam had travelled. "Good or bad, one's relationship with a free peopleis more healthy than with a subjected people", hedeclares (532). ${ }^{30}$

What then, is Leiris' attitude towards ethnography? Even as heistravelling and collecting data in Africa, he denounces the links that ethnography keeps with colonialism. As we have already stated, like all the surrealists, he is categorically opposed to colonialism. “To collect taxes, such is the main preoccupation. Pacification and medical assistance have only one purpose: to coax people into paying taxes without any resistance. [...] Ethnographic studies- for what purpose? To be ableto conduct a morecunning policy which will belikely to producegreater taxes" (169). ${ }^{31}$ So, in 1933, Leiris denounced ethnography because of its links with colonialism.

Someseventeen years later, after World War II, at the time of national ist movements in Africa, his views changed. He reconciled himself with ethnography to which he then ascribed an important role: not to enable "civilised" men to know themselves better, but to revalorisecultures which had been unjustly underrated. Hebelieved ethnography could give young nations "a basis for building their own future and [...] providethem with unchal lengeabledocuments to support all their claims" (4). ${ }^{32}$ So, in 1950, Leiris ascribed an important role to his ethnographic notes, his modest contribution to the knowledge of Africa.

But in 1981, disappointed by the continent's drift after 20 years of independence, Leirisconfesses in the preambleto his third edition that thetestimonial of hisjournal must only be considered as a "phantasm" by the people on whom the future of the new Africa largely depends (4). It was, indeed, a "Phantom Africa" which his notebooks of 1931-1933had presented. Africa'sleaders needed a stronger basisfor the building of their nationsthan theonehehad provided. Still, although hisethnographic notes had offered little to solve problems of nationhood and to foster national pride, as hehad somewhat ambitiously hoped, Leiris' journal provides a valuable insight into surrealist ethnographic activities and attitude to Africa.

\section{N otes}

1. Hereafter numbers in parentheses refer to Afrique fantôme (1981).

2. All translations from the French are the author's. "Écrivant subjectivement, j'augmente la valeur de mon témoignage, en montrant qu'à chaque instant, je sais à quoi m'en tenir sur ma valeur comme témoin" (213).

3. 'C'est en poussant à l'extrême le particulier que, bien souvent, on touche au général; en exhibant le coefficient personnel au grand jour, qu'on permet le calcul de l'erreur; en portant la subjectivité à son comble qu'on atteint l'objectivité" (213).

4. “Emportant ces objets, c'eût été la vie du pays que nous eussions emportée" (125).

5. "... il est convenu que cette nuit, Schaeffner et moi, nous irons nous en emparer" (128).

6. "Affreux chantage!" (82).

7. “... la vapeur du sacrilège commence réellement à nous monter à la tête et [...] d'un bond, nous nous trouvons jetés sur un plan de beaucoup supérieur à nous-mêmes" (82).

8. “Mon cœur bat très fort car, depuis le scandale d'hier, je perçois avec plus d'acuité l'énormité de ce que nous commettons" (83). 
9. "objet dont la découverte pourrait amener ni plus ni moins qu'un massacre" (469).

10. "Ce qui me pousse quant à moi, c'est l'idée de la profanation" (84).

11. “... je constate avec une stupeur qui, un certain temps après seulement, se transforme en dégoût, qu'on se sent tout de même joliment sûr de soi lorsqu'on est un blanc et qu'on tient un couteau dans sa main ..." (83).

12. "On ne pouvait voir les icônes abyssiniennes qu'en s'accroupissant et à la lumière d'un briquet" (Malraux 1976: 303).

13. "Aux officiels [...] qui estimeraient que décidément nous en prenons trop à notre aise dans nos transactions avec les nègres, il serait aisé de répondre que, tant que l'Afrique sera soumise à un régime aussi inique que celui de l'impôt, des prestations et du service militaire sans contre-partie, ce ne sera pas à eux de faire la petite bouche à propos d'objets enlevés ou achetés à un trop juste prix" (89-90).

14. “'ces nègres sont tous les mêmes' [... ] il n'y a de bon pour les faire marcher que les coups de trique" (172).

15. "souvent [...] pour des crimes qui ne sont crimes qu'à nos yeux" (173).

16. "Ces hommes, peut-être pas spécialement sympathiques, mais en tout cas pas plus stupides ni plus mauvais que tous les autres, les traiter ainsi sous couleur de civilisation, quelle honte!" (173).

17. “...je me sens très séparé, très saint, très élu” (443).

18. "Il faut vraiment que ce soit le zar qui mange, non le 'cheval', car je ne me serais jamais soupçonné une telle capacité" (443).

19. "Pauvres awolya, combien doit-il falloir qu'ils se battent les flancs pour parvenir à leurs transes, à leur folie de pacotille ..." (401).

20. "Les zar [...] ne me sont plus que des parents ..." (401).

21. "L'humanité à l'aube de temps [...] sans civilisation" (Gide 1930: 21).

22. “... le cerveau gourd et stagnant, le plus souvent dans une nuit épaisse” (Gide 1954: 765).

23. "Plus ou moins enfoui sous les sédiments patiemment apportés par la culture, se trouve le moi 'barbare' qu'il est fascinant de retrouver à l'état natif" (Gide 1988: 35).

24. "Merveilleux sauvages, si nonchalants, si inattendus, en même temps que si étonnamment pareils à ceux qu'on imagine ..." (223).

25. "Voici enfin l'AFRIQUE, la terre des 50 à l'ombre, des convois d'esclaves, des festins cannibales, des crânes vides, de toutes les choses qui sont mangées, corrodées, perdues" (225).

26. "un monument biblique" (434).

27. "Le voyage ne nous change que par moments. La plupart du temps, vous restez tristement pareil à ce que vous aviez toujours été" (181).

28. "pleine existence" (3).

29. “. ... une science humaine reste une science et l'observation détachée ne saurait, à elle seule, amener le contact; peut-être, par définition, impliquet-elle même le contraire, l'attitude d'esprit propre à l'observateur étant une objectivité impartiale ennemie de toute effusion" (8).

30. "Bons ou mauvais, I'on a des rapports plus sains avec des gens libres qu'avec des gens sous tutelle" (532).

31. "Faire rentrer l'impôt, telle est la grande préoccupation. Pacification, assistance médicale n'ont qu'un but: amadouer les gens pour qu'ils se laissent faire et payent l'impôt. [...] Étude ethnographique dans quel but: être à même de mener une politique plus habile qui sera mieux à même de faire rentrer l'impôt" (169).

32. “...fournir aux gens qu'on étudie des données pour la construction d'un avenir qui leur sera propre et [...] produire des pièces difficilement récusables à l'appui de leurs revendications" (4).

\section{Works cited}

Breton, André. 1952. Radiophonic interviews.

Clifford, J. 1988. The Predicament of Culture: Twentieth-Century Ethnography, Literature and Art. Cambridge, London: Harvard University Press.

Davidson, Patricia. 1993. Different visions: a comparison of the central African collections of W.F. Burton and Irma Stern. Social Dynamics, 19(1): 26-38. 
Diawara, Manta. 1992. African Cinema . Bloomington and Indianapolis: Indiana University Press.

Durosay, Daniel. 1991. Retrouvé à Berlin: “Reise zum Kongo”. Bulletin des A mis d'André Gide 89. Janvier, 7-26.

Gide, André. 1954. Voyage au Congo. Retour du Tchad (Journal 1939-1949). Paris: Pléiade.

1988 [1929]. Conférence de Bruxelles. Bulletin des A mis d'André Gide 80, Octobre. 31-36.

Leiris, Michel. 1981. Afrique fantôme. Paris: Gallimard.

1950. Ethnographical Studies. Paris: Gonthier.

Malraux, André. 1976. Le miroir des Limbes. Paris: Gallimard. 